\title{
Solar gas turbine systems: Design, cost and perspectives
}

\author{
Peter Schwarzbözl ${ }^{\mathrm{a}, *}$, Reiner Buck ${ }^{\mathrm{a}}$, Chemi Sugarmen ${ }^{\mathrm{b}}$, Arik Ring ${ }^{\mathrm{b}}$, \\ $\mathrm{M}^{\mathrm{a}}$ Jesús Marcos Crespo $^{\mathrm{c}}$, Peter Altwegg ${ }^{\mathrm{d}}$, Juan Enrile ${ }^{\mathrm{e}}$ \\ ${ }^{a}$ Solar Research, Institute of Technical Thermodynamics, German Aerospace Centre (DLR), 51170 Köln, Germany \\ ${ }^{\mathrm{b}}$ Research \& Development Department, ORMAT Industries LTD., Industrial Area, P.O. Box 68, Yavne 81100, Israel \\ ${ }^{\mathrm{c}}$ Renewable Energy Department, CIEMAT, Avda. Complutense 22, 28040 Madrid, Spain \\ ${ }^{d}$ TURBOMACH SA, CH-6595 Riazzino, Switzerland \\ e SOLUCAR, Avda. de la Buhaira, 2, 41018 Sevilla, Spain
}

Received 26 August 2004; received in revised form 27 September 2005; accepted 29 September 2005

Available online 2 November 2005

\begin{abstract}
The combination of high solar shares with high conversion efficiencies is one of the major advantages of solar gas turbine systems compared to other solar-fossil hybrid power plants. Pressurized air receivers are used in solar tower plants to heat the compressed air in the gas turbine to temperatures up to $1000{ }^{\circ} \mathrm{C}$. Therefore solar shares in the design case of $40 \%$ up to $90 \%$ can be realized and annual solar shares up to $30 \%$ can be achieved in base load. Using modern gas turbine systems in recuperation or combined cycle mode leads to conversion efficiencies of the solar heat from around $40 \%$ up to more than $50 \%$. This is an important step towards cost reduction of solar thermal power. Together with the advantages of hybrid power plants - variable solar share, fully dispatchable power, $24 \mathrm{~h}$ operation without storage - solar gas turbine systems are expected to have a high potential for market introduction in the mid term view.

In this paper the design and performance assessment of several prototype plants in the power levels of $1 \mathrm{MW}, 5 \mathrm{MW}$ and $15 \mathrm{MW}$ are presented. Advanced software tools are used for design optimization and performance prediction of the solar tower gas turbine power plants. Detailed cost assumptions for the solarized gas turbine, the solar tower plant and further equipment as well as for operation and maintenance are presented. Intensive performance and economic analysis of the prototype plants for different locations and capacity factors are shown. The cost reduction potential through automation and remote operation is revealed.
\end{abstract}

(C) 2005 Elsevier Ltd. All rights reserved.

Keywords: Solar thermal power; Solar-fossil hybrid power generation; Solar gas turbine; Solar tower plant; Pressurized air receiver; Solar incremental cost

\section{Introduction}

The reduction of fossil-fuel based power production by using solar power technology is one impor-

\footnotetext{
* Corresponding author. Fax: +49 220366900.

E-mail address: peter.schwarzboezl@dlr.de (P. Schwarzbözl).
}

tant step in the international commitment of $\mathrm{CO}_{2}$ reduction. The direct way of producing electric power from solar energy, the photovoltaic technology (PV), is gradually extending its focus from purely decentralized small-scale systems towards large-area bulk power production. While current PV system prices are still around $5000 € / \mathrm{kW}_{\mathrm{p}}$, a cost 


\author{
Nomenclature \\ Variables \\ $E \quad$ energy \\ $A \quad$ aperture area \\ $\eta \quad$ efficiency \\ $\rho \quad$ reflectivity \\ $\Delta \quad$ incremental value
}

\section{Subscripts}

cos cosine effect

el electric power

ref fossil reference system

\author{
Acronyms \\ DNI direct normal irradiation \\ LEC levelized electricity cost \\ PSA Plataforma Solar de Almerá \\ REFOS receiver for fossil-hybrid gas turbine \\ systems \\ TRR total revenue requirement
}

reduction for very large-scale $\mathrm{PV}$-systems ( $>10 \mathrm{MW}$ ) to $2000 € / \mathrm{kW}_{\mathrm{p}}$ and below is predicted for the future $(2010+)$. Generating costs of solar electricity of 5 $10 €$ cent $/ \mathrm{kW} \mathrm{h}$ could then make this technology profitable (Kurokawa, 2003). In contrast, solar thermal power plants produce high-temperature heat that is converted to electricity by conventional power cycles. The nine commercial parabolic trough plants in the Californian dessert (SEGS) were built with system costs of $3000-4500 € / \mathrm{kW}$. They produce electricity from solar energy with an annual solarto-electric efficiency of $10-14 \%$ and at a levelized cost of 16-19 €cent $/ \mathrm{kW} \mathrm{h}$. Future large systems of $200 \mathrm{MW}$ with $12 \mathrm{~h}$ storage are forecasted with system costs of $2500 € / \mathrm{kW}$ and generating costs below $5 €$ cent $/ \mathrm{kW}$ h (Price et al., 2002). Similar projections are made for other solar-only technologies. In any case, the key to cost reduction lies in mass production after successful market penetration.

One major option for the accelerated market introduction of solar thermal power technology are solar-fossil hybrid power plants. Their advantage, compared to solar-only systems, lies in low additional investment due to an adaptable solar share, reduced technical and economical risks due to fully dispatchable power, and higher system efficiency because of reduced part load operation and fewer start-up and shutdown-losses. And another important aspect can be put forward in favor of hybrid systems: until thermal or chemical storage technologies allow for guaranteed and predictable power delivery to the grid, a conventional power capacity has to be kept on stand-by to compensate the fluctuating power supply of renewable energies. ${ }^{1}$ This is a kind of renewable-

\footnotetext{
${ }^{1}$ This is the case already today for photovoltaics and wind power at least in developed countries.
}

conventional hybrid power system but with completely separated system technology leading to economic drawbacks! Real hybrid plants share much of their system, hence leading to economic advantages. A solar-fossil hybrid technology with short-term perspectives is the integrated solar combined cycle system (ISCCS), where thermal power from parabolic troughs is integrated into the bottom cycle of a combined cycle power plant (Dersch et al., 2004). With this option, the generation cost of solar $\mathrm{kW} \mathrm{h}$ is remarkably low ( $9 €$ cent $/ \mathrm{kW} \mathrm{h}$ without, $7.5 €$ cent/ $\mathrm{kW} \mathrm{h}$ with thermal storage for a $310 \mathrm{MW}_{\mathrm{e}}$ ISCCS in California), but the achievable annual solar share is restricted (4\% without, $9 \%$ with thermal storage).

In the following paragraphs, the potential of solar-fossil hybrid gas turbine systems will be described to be compared with the above mentioned technologies.

\section{Solar-hybrid gas turbine technology}

Solar gas turbine systems use concentrated solar power to heat the pressurized air in a gas turbine before entering the combustion chamber (Figs. 1 and 2). The solar heat can therefore be converted with the high thermal efficiency of a modern recuperated or combined gas turbine cycle. The combustion chamber closes the temperature gap between the receiver outlet temperature $\left(800-1000{ }^{\circ} \mathrm{C}\right.$ at design point) and the turbine inlet temperature $\left(950-1300^{\circ} \mathrm{C}\right)$ and provides constant turbine inlet conditions despite fluctuating solar input. The solar power tower technology is used with concentration ratios up to 1000 suns to achieve the high receiver temperatures.

A pressurized volumetric air receiver with a secondary concentrator has been developed and suc- 


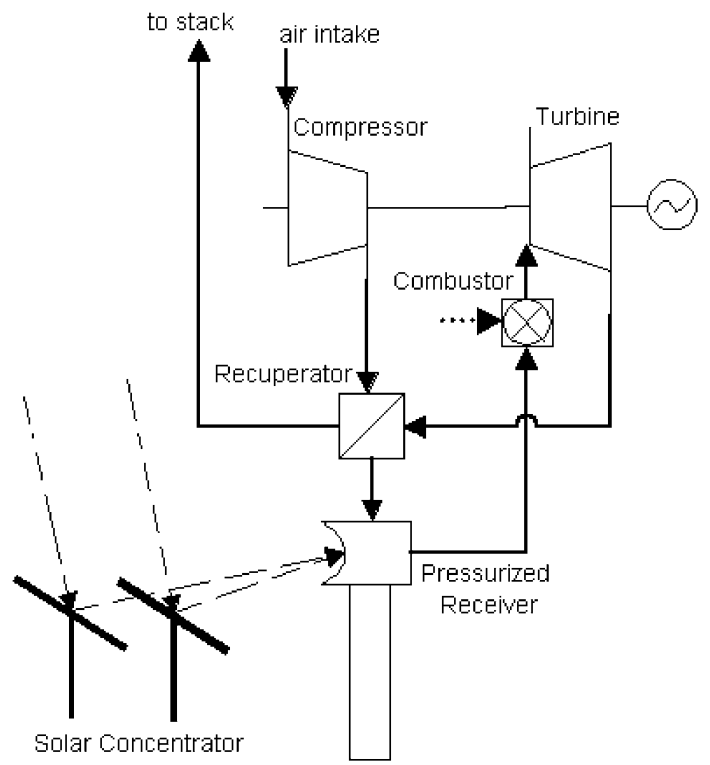

Fig. 1. Solarized gas turbine plant schematic: recuperated Brayton cycle.

cessfully tested, the so-called REFOS receiver technology in the scope of several German national and international $R \& D$ projects (Buck et al., 2000, 2002). In 2002, three receiver modules were coupled in series to a $240 \mathrm{~kW}_{\mathrm{e}}$ gas turbine and successfully operated at receiver temperatures of up to $800{ }^{\circ} \mathrm{C}$ (Sugarmen et al., 2003). More detailed information about the receiver development and recent test results with receiver temperatures up to $960^{\circ} \mathrm{C}$ can be found in Heller et al. (2005).

\section{Layout, optimization and performance calculation}

Modern computer based simulation models have been developed and adapted to analyze the performance of solar-hybrid gas turbines in commercial system size. The design of the optical part of the tower system (concentrator field arrangement and size, secondary acceptance angle, receiver aperture and orientation and tower height) can be cost-optimized using an adapted version of the HFLCAL code (Becker and Böhmer, 1989; Schwarzbözl et al., 2002, Fig. 3). The simulation environment TRNSYS with the model library STEC is used (Pitz-Paal and Jones, 1998; TRNSYS STEC, 2002, Fig. 4) for the annual performance calculation of the thermal power system. The link between the optical and the thermal models is realized with a 'field efficiency matrix', based on the fact that for a fixed layout of the solar part at a given location the heliostat field efficiency only depends on the solar angles (Eq. (1)). Both models were validated against measurement data from the solar experiments at the PSA 2002/2003.

$$
\begin{aligned}
\eta_{\text {Field }}= & \rho_{\text {Mirror }} \times \eta_{\text {cos }} \times \eta_{\text {Block \& Shadow }} \times \eta_{\text {Atmosph.Att. }} \\
& \times \eta_{\text {Intercept }} \times \eta_{\text {Secondary }}=f(\text { Azimuth }, \text { Elevation }) .
\end{aligned}
$$

Three industrial gas turbine systems are chosen for detailed technical and economical analysis as potential solar-hybrid prototype plants:

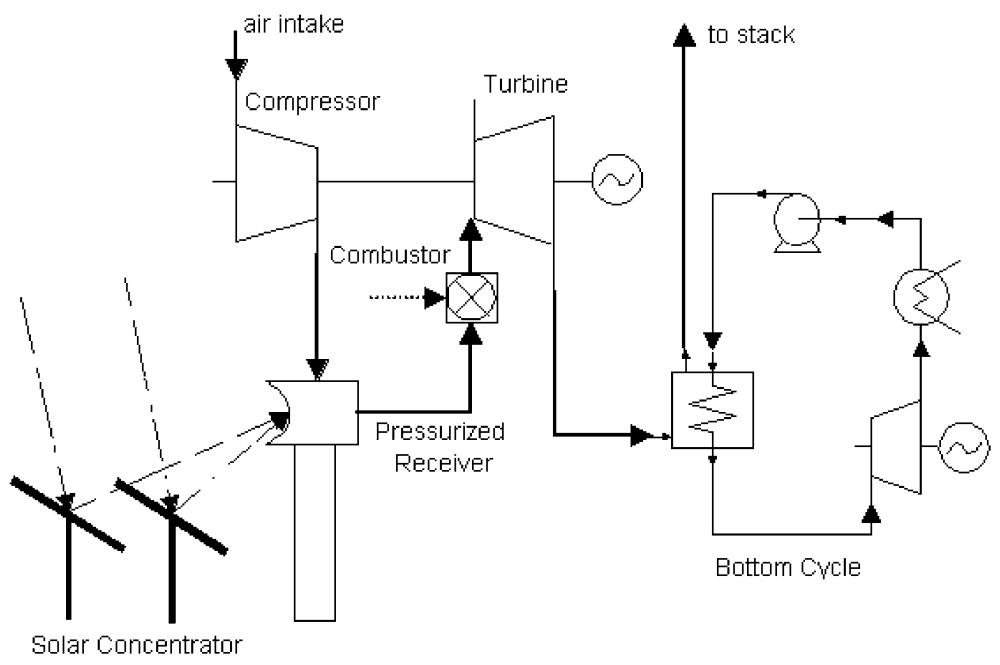

Fig. 2. Solarized gas turbine plant schematic: combined Brayton and Rankine cycle. 


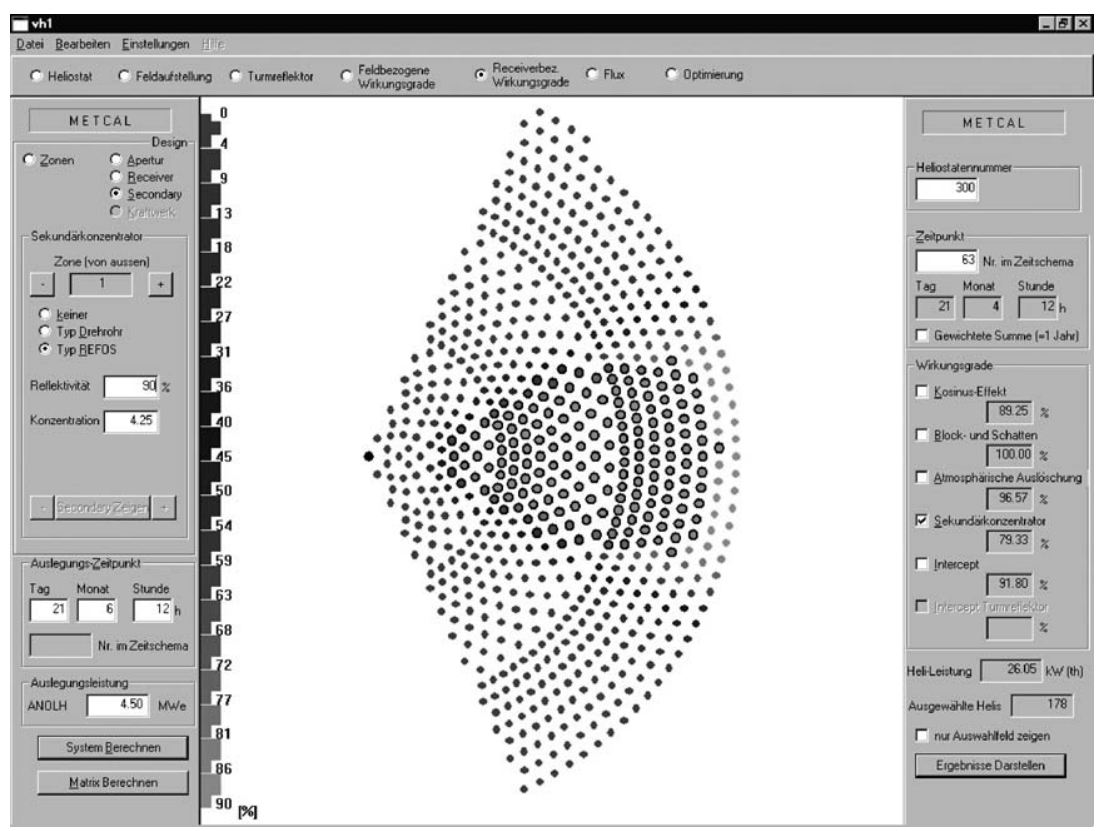

Fig. 3. Software for layout of solar gas turbine systems (screenshot of HFLCAL showing heliostat field arrangement with limited receiver acceptance angle).

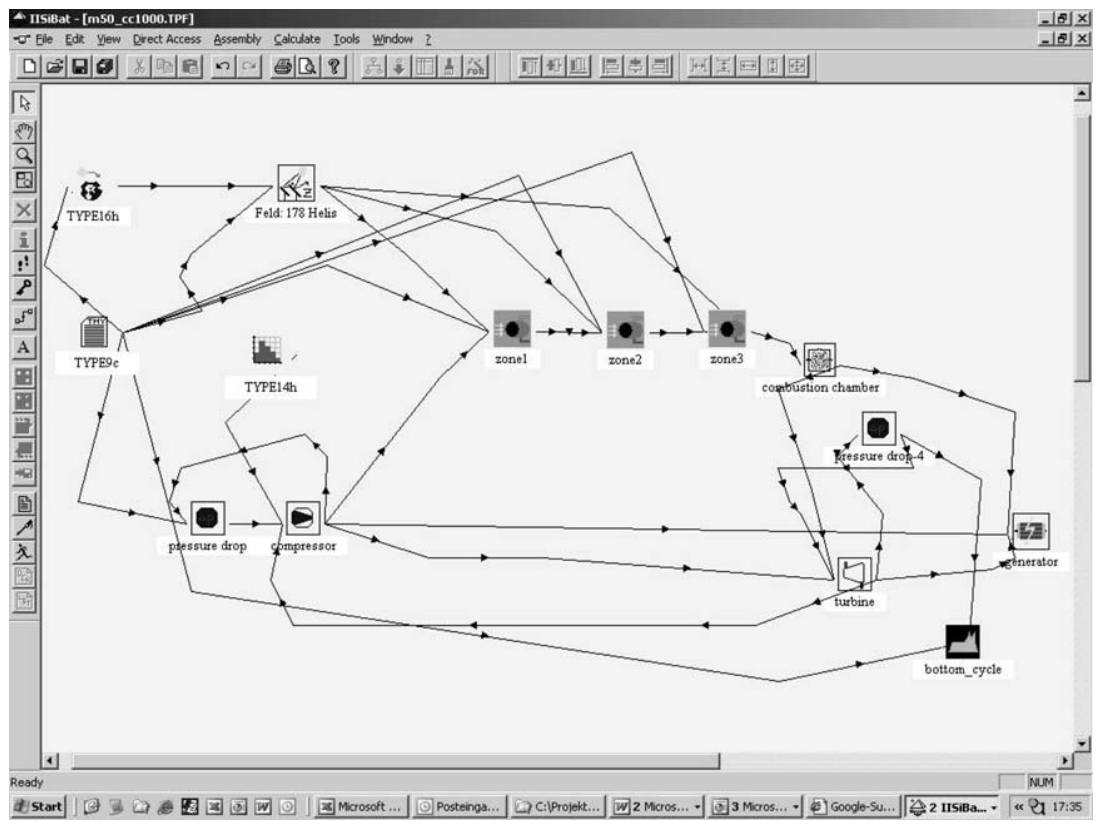

Fig. 4. Software for performance calculation of solar gas turbine systems (screenshot of TRNSYS STEC for solar-hybrid gas turbine with three serial receiver zones).

- Heron H1-intercooled recuperated two-shaft engine with reheat. ISO rating $1400 \mathrm{MW}$, thermal efficiency $42.9 \%$.
- Solar Mercury 50 - recuperated single shaft gas turbine. ISO rating $4200 \mathrm{MW}$, thermal efficiency $40.3 \%$. 
- PGT 10-simple gas turbine with bottom cycle. ISO rating $11100 \mathrm{MW}$ (gas turbine) respectively $16100 \mathrm{MW}$ (combined cycle), thermal efficiency $31.3 \%$ (gas turbine) respectively $44.6 \%$ (combined cycle).

The solarization adds a receiver cluster directly before each combustion chamber for solar preheating of the compressed air. The maximum receiver exit temperature is designed to be $800{ }^{\circ} \mathrm{C}$. One case with a receiver design exit temperature of $1000^{\circ} \mathrm{C}$ is analyzed. The receiver design temperature rules the maximum solar share. Two possible locations are chosen for the analysis: Seville (Spain) as a very good European site with interesting market perspectives and Daggett (California, USA) as a very high solar potential site (Table 1).

Table 2 summarizes the cost-optimized layout of the prototype plants for the chosen locations, Seville and Daggett.

Figs. 5-8 show the layout of the solarized gas turbine plants for Daggett. Each receiver zone consists of a group of parallel connected single receiver modules. Receivers are subdivided into low-temperature (up to $600{ }^{\circ} \mathrm{C}$ ), medium-temperature (up to $800^{\circ} \mathrm{C}$ ) and high-temperature modules (up to $1000^{\circ} \mathrm{C}$ ). According to their temperature level, receiver zones are located in the low-, medium- and high-flux region of the focal spot (Schwarzbözl et al., 2002). The averaged design flux density for each receiver zone is indicated in the schematics of the plants.
The annual performance of the prototype plants was calculated by simulation of the system operation with the TRNSYS STEC software using a typical meteorological year on hourly basis for each location. The results for $24 \mathrm{~h}$ operation are summarized in the upper half of Table 5. The solar incremental electricity is defined as the annual amount of net electricity produced by the solar-hybrid plant compared to the pure fossil reference plant (i.e. same gas turbine system without solarization) using the same amount of fuel (Eq. (2)).

$$
\begin{aligned}
\Delta_{E_{\mathrm{el}}} & =E_{\text {el,hybrid }}-\frac{E_{\mathrm{el}, \mathrm{ref}}}{E_{\text {fuel,ref }}} \cdot E_{\text {fuel,hybrid }} \\
& =E_{\text {el,hybrid }}-\eta_{\text {ref }} \cdot E_{\text {fuel,hybrid }}
\end{aligned}
$$

Using this definition, all drawbacks of the solarization (e.g. additional pressure drop) are assigned to the solar part and we get a fair basis for comparing hybrid systems of different solar share with each other and with pure fossil plants. All other figures of merit are derived from the solar incremental electricity (Table 3 ). The incremental solar share varies according to the receiver inlet- and outlet-temperatures between $7.5 \%$ and $28 \%$ for $24 \mathrm{~h}$ operation (Table 5).

Figs. 9 and 10 show the change of the incremental solar share when reducing the capacity factor by limiting the operation to daytime only or sun hours only. A solar share of up to $70 \%$ is reached with the $1000{ }^{\circ} \mathrm{C}$-Daggett case for $40 \%$ capacity factor

Table 1

Definition of plant locations and design points

\begin{tabular}{lll}
\hline & Seville $\left(37.2^{\circ} \mathrm{N}\right)$ & Daggett $\left(34.9^{\circ} \mathrm{N}\right)$ \\
\hline Annual DNI & $2015 \mathrm{~kW} \mathrm{~h} / \mathrm{m}^{2}$ & $2790 \mathrm{~kW} \mathrm{~h} / \mathrm{m}^{2}$ \\
Design point definition & 21.3 noon, $800 \mathrm{~W} / \mathrm{m}^{2}$ & $21.3 \mathrm{noon}, 880 \mathrm{~W} / \mathrm{m}^{2}$ \\
Design point conditions & $25^{\circ} \mathrm{C}, 1011 \mathrm{mbar}, 60 \%$ r.h. & $25^{\circ} \mathrm{C}, 941 \mathrm{mbar}, 20^{\circ}$ r.h. \\
\hline
\end{tabular}

Table 2

\begin{tabular}{|c|c|c|c|c|c|c|c|}
\hline & Seville & & & Daggett & & & \\
\hline Gas turbine system & Heron $\mathrm{H} 1$ & Mercury 50 & PGT10 CC & Heron $\mathrm{H} 1$ & Mercury 50 & PGT10 CC & PGT10 CC \\
\hline Solar design temperature & $800{ }^{\circ} \mathrm{C}$ & $800^{\circ} \mathrm{C}$ & $800^{\circ} \mathrm{C}$ & $800^{\circ} \mathrm{C}$ & $800{ }^{\circ} \mathrm{C}$ & $800^{\circ} \mathrm{C}$ & $1000^{\circ} \mathrm{C}$ \\
\hline Design point solar share & $75 \%$ & $38 \%$ & $57 \%$ & $75 \%$ & $38 \%$ & $58 \%$ & $88 \%$ \\
\hline Total receiver aperture & $7.42 \mathrm{~m}^{2}$ & $12.90 \mathrm{~m}^{2}$ & $58.61 \mathrm{~m}^{2}$ & $6.88 \mathrm{~m}^{2}$ & $12.18 \mathrm{~m}^{2}$ & $54.60 \mathrm{~m}^{2}$ & $82.32 \mathrm{~m}^{2}$ \\
\hline Tower height & $41.2 \mathrm{~m}$ & $50.6 \mathrm{~m}$ & $103.7 \mathrm{~m}$ & $39.6 \mathrm{~m}$ & $50.6 \mathrm{~m}$ & $100.2 \mathrm{~m}$ & $130.2 \mathrm{~m}$ \\
\hline Total reflective area & $5460 \mathrm{~m}^{2}$ & $8615 \mathrm{~m}^{2}$ & $41620 \mathrm{~m}^{2}$ & $5732 \mathrm{~m}^{2}$ & $8615 \mathrm{~m}^{2}$ & $37615 \mathrm{~m}^{2}$ & $62733 \mathrm{~m}^{2}$ \\
\hline Total plant area ${ }^{a}$ & $0.06 \mathrm{~km}^{2}$ & $0.09 \mathrm{~km}^{2}$ & $0.43 \mathrm{~km}^{2}$ & $0.04 \mathrm{~km}^{2}$ & $0.07 \mathrm{~km}^{2}$ & $0.37 \mathrm{~km}^{2}$ & $0.47 \mathrm{~km}^{2}$ \\
\hline
\end{tabular}

Results of layout and cost-optimization of prototype plants

\footnotetext{
a Total plant area stands for rectangular envelope of used land area.
} 


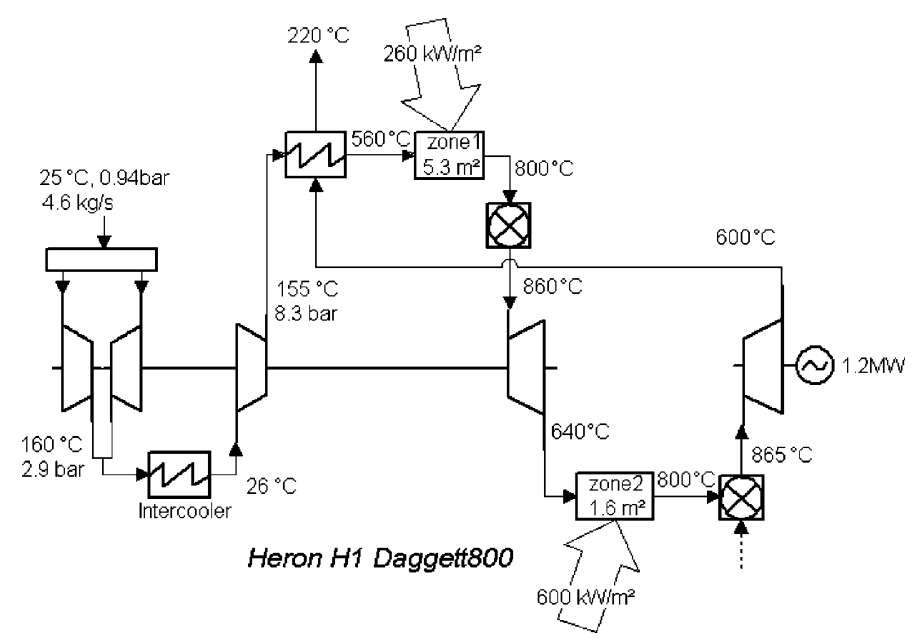

Fig. 5. Solarized gas turbine prototype plant: Heron unit (location Daggett).

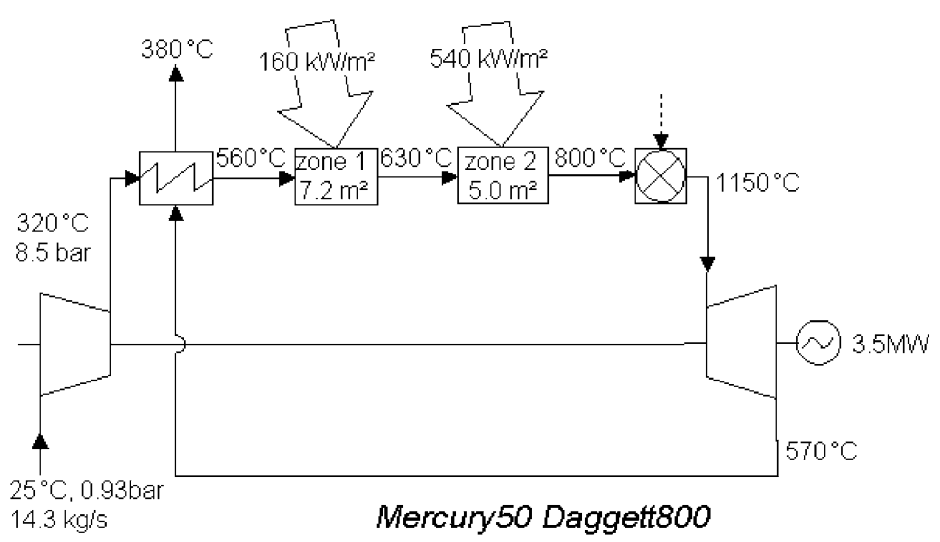

Fig. 6. Solarized gas turbine prototype plant: Mercury unit (location Daggett).

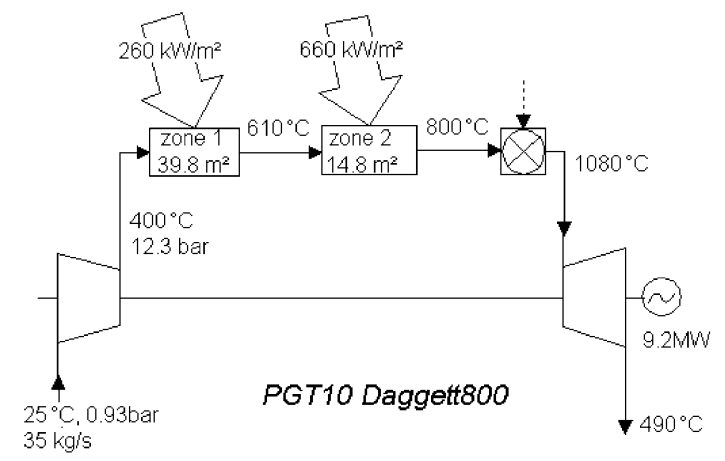

Fig. 7. Solarized gas turbine prototype plant: PGT10 unit, $800{ }^{\circ} \mathrm{C}$ (location Daggett).

(about 3400 annual operation hours, a typical midload plant). For the incremental solar to electric efficiency values of $14-19 \%$ are reached with the prototype plants analyzed here.

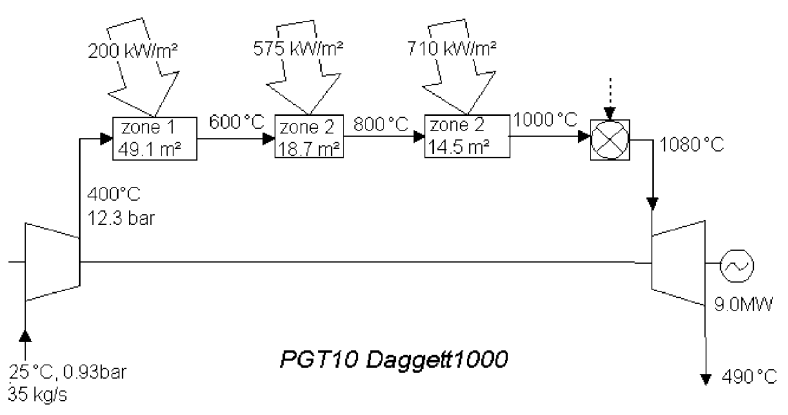

Fig. 8. Solarized gas turbine prototype plant: PGT10 unit, $1000{ }^{\circ} \mathrm{C}$ (location Daggett).

\section{Economic analysis}

For economic analysis, an emerging market for solar tower plants is assumed with concentrator 
Table 3

Definition of derived figures of merit

\begin{tabular}{|c|c|}
\hline $\begin{array}{l}\text { Incremental solar } \\
\text { share }\end{array}$ & $\Delta_{\text {solarshare }}=\Delta_{E_{\mathrm{el}}} / E_{\mathrm{el}, \text { hybrid }}$ \\
\hline $\begin{array}{l}\text { Incremental } \mathrm{CO}_{2} \\
\text { avoidance }\end{array}$ & $\begin{aligned} \Delta_{\mathrm{CO}_{2}} & =\left(E_{\text {el }, \text { hybrid }} / \eta_{\text {ref }}-E_{\text {fuel,hybrid }}\right) \cdot f_{\mathrm{CO}_{2}} \\
& =\left(\Delta_{E_{\text {el }}} / \eta_{\text {ref }}\right) \cdot f_{\mathrm{CO}_{2}}\end{aligned}$ \\
\hline $\begin{array}{l}\text { Incremental solar to } \\
\text { electric efficiency }\end{array}$ & $\Delta_{\eta_{\text {solel }}}=\Delta_{E_{\text {el }}} / A_{\text {Hel.field }} \cdot \int_{1 a} D N I(t) \mathrm{d} t$ \\
\hline $\begin{array}{l}\text { Solar incremental } \\
\text { LEC }\end{array}$ & $\begin{array}{l}\text { (levelized TRR }-\left(E_{\text {el,hybrid }}-\Delta_{E_{\mathrm{el}}}\right) \\
\left.\quad \cdot \mathrm{LEC}_{\mathrm{ref}}\right) / \Delta_{E_{\mathrm{el}}}\end{array}$ \\
\hline
\end{tabular}

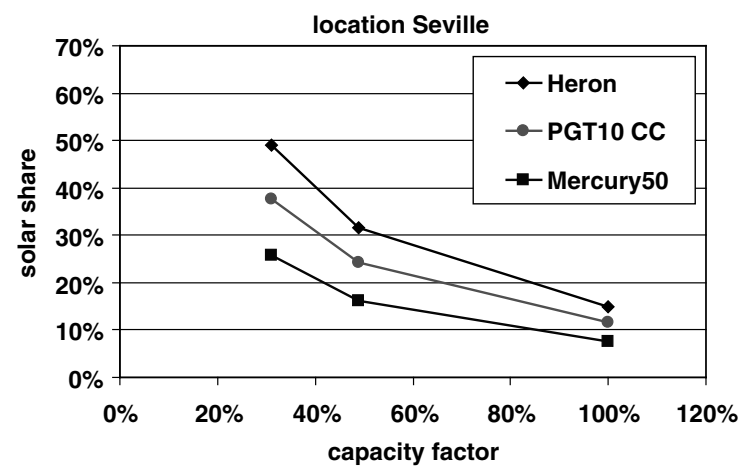

Fig. 9. Result of performance calculation: incremental solar share as a function of capacity factor for location Seville.

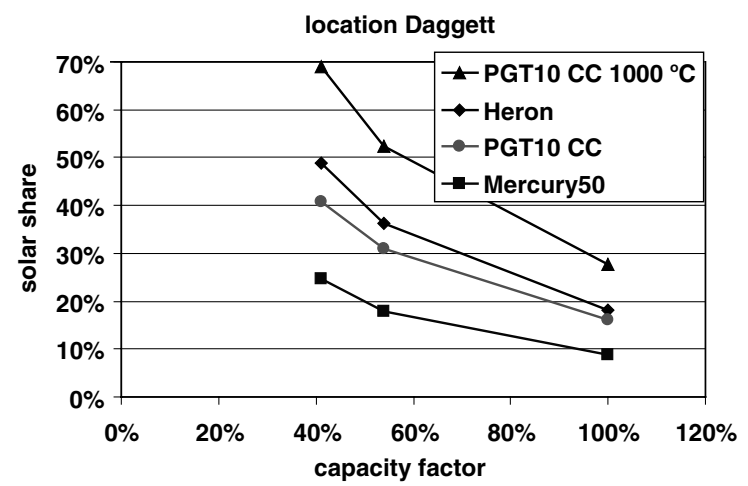

Fig. 10. Result of performance calculation: incremental solar share as a function of capacity factor for location Daggett.

costs of $132 € / \mathrm{m}^{2}$ (for $120 \mathrm{~m}^{2}$ glass-metal heliostat). The receiver costs are $16 \mathrm{k} € / \mathrm{m}^{2}, 33 \mathrm{k} € / \mathrm{m}^{2}$ and $37.5 \mathrm{k} € / \mathrm{m}^{2}$ for the low-, medium- and high-temperature receiver. The investment costs for the conventional part (power block, fuel system, cooling system, generator, grid connection) are $1520 € / \mathrm{kW}$ for the Heron system, $560 € / \mathrm{kW}$ for the Mercury system and $510 € / \mathrm{kW}$ for the PGT10 combined cycle system.
For detailed cost calculations two types of plant projects are notable with regard to investment and operational cost assumptions:

- 1st plant (stand-alone)

- 'first-of-its-kind' plant with completely new plant engineering,

- covering all expenses for engineering and development of gas turbine solarization (i.e. adaptation of combustion chamber and control),

- fully operated by the staff on site (3 shifts for $24 \mathrm{~h}$ operation).

- 2nd generation plant (remote in virtual park)

- gas turbine solarization costs shared amongst 10 similar plants,

- operated remotely in a 'virtual park' of 4 similar plants,

- high degree of automation,

- reduced expenses for instrumentation, controland auxiliary equipment,

- reduced general engineering and construction costs,

- reduced personnel expenses due to shared staff for operation and maintenance.

For calculation of levelized electricity costs (LEC) financial parameters are assumed according to Table 4 and Fig. 11.

The results of the LEC calculations can be found in Table 5. The total LEC for a 1st plant range from about $6.3 €$ cent $/ \mathrm{kW}$ h to $19.9 €$ cent $/ \mathrm{kW}$ h depending on power level and solar share. The solar incremental LEC are calculated according to Table 3. They range from $12.7 €$ cent $/ \mathrm{kW}$ h to $89.7 €$ cent/ $\mathrm{kW}$ h for the 1 st plant. The lower part of Table 5 shows the cost reduction that can be achieved by 2nd generation plants with remote operation and

Table 4

Additional parameters for performance and LEC calculation

\begin{tabular}{lll}
\hline Fuel heat rate & $\mathrm{kJ} / \mathrm{kg}$ & 42100 \\
Specific $\mathrm{CO}_{2}$ emissions $\left(f_{\mathrm{CO}_{2}}\right)$ & $\mathrm{kg} / \mathrm{MW} \mathrm{h} \mathrm{h}_{\text {fuel }}$ & 200 \\
Losses due to outages & $\%$ & 2.5 \\
Parasitic losses: Heron \& Mercury & $\%$ & 1 \\
PGT10 CC & $\%$ & 2.5 \\
Debt-equity ratio & - & $75: 25$ \\
Debt interest rate & $\%$ & 4.2 \\
Equity interest rate & $\%$ & 14 \\
Debt payback time & $\mathrm{a}$ & 12 \\
Plant operation time & $\mathrm{a}$ & 20 \\
General inflation rate & $\%$ & 2.5 \\
Fuel cost & $€ / \mathrm{MW} \mathrm{h}$ & 13.43 \\
\hline
\end{tabular}




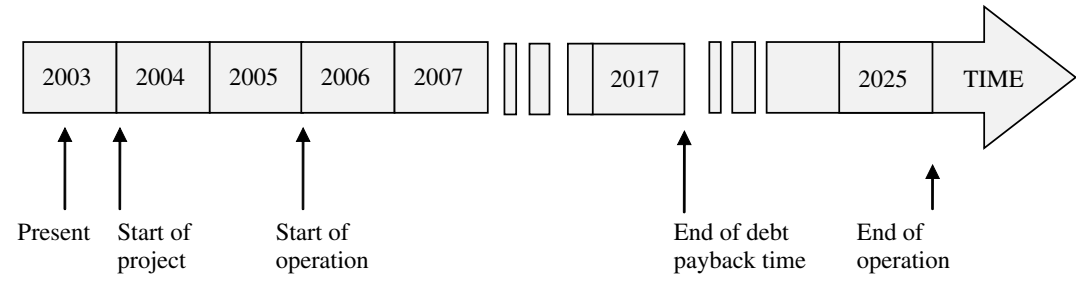

Fig. 11. Time schedule assumptions for prototype plant projects.

Table 5

Summary of results of performance calculation and cost analysis for $24 \mathrm{~h}$ operation

\begin{tabular}{|c|c|c|c|c|c|c|c|c|}
\hline Name & & sev_H1 & dag_H1 & sev_M50 & dag_M50 & sev_PGT10 & dag_PGT10 & dag_PGT10_1000 \\
\hline Power system & & Heron-HI & Heron-HI & Mercury 50 & Mercury 50 & PGT10 & PGT10 & PGT10 \\
\hline ISO rating & {$[\mathrm{MW}]$} & 1.4 & 1.4 & 4.2 & 4.2 & 16.1 & 16.1 & 16.1 \\
\hline Location & & Sevilla & Daggett & Sevilla & Daggett & Sevilla & Daggett & Daggett \\
\hline Annual DNI & {$\left[\mathrm{kW} \mathrm{h} / \mathrm{m}^{2}\right]$} & 2015 & 2791 & 2015 & 2791 & 2015 & 2791 & 2791 \\
\hline Capacity factor & {$[\%]$} & $100 \%$ & $100 \%$ & $100 \%$ & $100 \%$ & $100 \%$ & $100 \%$ & $100 \%$ \\
\hline Annual field efficiency & {$[\%]$} & $52.7 \%$ & $56.1 \%$ & $55.8 \%$ & $60.4 \%$ & $54.1 \%$ & $57.9 \%$ & $55.8 \%$ \\
\hline Annual receiver efficiency & {$[\%]$} & $79.0 \%$ & $77.2 \%$ & $78.9 \%$ & $79.9 \%$ & $73.3 \%$ & $75.4 \%$ & $75.3 \%$ \\
\hline Annual power cycle efficiency & {$[\%]$} & $40.4 \%$ & $38.4 \%$ & $35.9 \%$ & $35.9 \%$ & $44.9 \%$ & $43.4 \%$ & $43.9 \%$ \\
\hline Net electric energy & {$[\mathrm{MW} \mathrm{h}]$} & 11259 & 10610 & 32842 & 32769 & 130999 & 125612 & 119678 \\
\hline Solar incremental electricity & {$[\mathrm{MW} \mathrm{h}]$} & 1689 & 1918 & 2459 & 2871 & 15251 & 20298 & 33237 \\
\hline Incremental solar share & {$[\%]$} & $15.0 \%$ & $18.1 \%$ & $7.5 \%$ & $8.8 \%$ & $11.6 \%$ & $16.2 \%$ & $27.8 \%$ \\
\hline $\begin{array}{l}\text { Incremental } \mathrm{CO}_{2} \text { avoidance } \\
\text { Incremental solar to electric }\end{array}$ & {$[\mathrm{t} / \mathrm{a}]$} & 826 & 972 & 1359 & 1576 & 6837 & 9438 & 15454 \\
\hline Efficiency & {$[\%]$} & $15.4 \%$ & $14.5 \%$ & $14.2 \%$ & $14.6 \%$ & $18.3 \%$ & $19.3 \%$ & $19.0 \%$ \\
\hline \multicolumn{9}{|l|}{ 1st plant (stand alone) } \\
\hline Total investment costs & {$[\mathrm{k} €]$} & 8632 & 8456 & 8974 & 8678 & 25406 & 24578 & 31155 \\
\hline There of solar equipment & & $22 \%$ & $21 \%$ & $27 \%$ & $26 \%$ & $33 \%$ & $32 \%$ & $40 \%$ \\
\hline Spec. investment costs & {$\left[€ / \mathrm{kW}_{\mathrm{e}}\right]$} & 6640 & 7046 & 2362 & 2480 & 1728 & 1731 & 2225 \\
\hline Fixed O\&M costs & {$[\mathrm{k} € / \mathrm{a}]$} & 1032 & 1028 & 1337 & 1331 & 2090 & 2072 & 2419 \\
\hline Thereof personal expenses & & $69 \%$ & $70 \%$ & $58 \%$ & $59 \%$ & $53 \%$ & $54 \%$ & $54 \%$ \\
\hline \multicolumn{8}{|l|}{ Levelized electricity costs } & 0.0694 \\
\hline Reference plant LB3 & {$[€ / \mathrm{kW} \mathrm{h}]$} & 0.0667 & 0.0698 & 0.0563 & 0.0563 & 0.0458 & 0.0474 & 0.0474 \\
\hline $\mathrm{CO}_{2}$-avoidance cost & {$[€ / \mathrm{kg}]$} & 1.6976 & 1.4129 & 1.0655 & 0.8843 & 0.3318 & 0.2125 & 0.1708 \\
\hline Solar incremental LEG & {$[€ / \mathrm{kW} \mathrm{h}]$} & 0.8969 & 0.7857 & 0.6452 & 0.5417 & 0.1945 & 0.1462 & 0.1268 \\
\hline \multicolumn{9}{|c|}{ 2nd generation plant (remote in virtual park) } \\
\hline Total investment costs & {$[\mathrm{k} €]$} & 5763 & 5595 & 6583 & 6302 & 21206 & 20421 & 26023 \\
\hline Thereof solar equipment & & $31 \%$ & $30 \%$ & $36 \%$ & $34 \%$ & $39 \%$ & $37 \%$ & $47 \%$ \\
\hline Spec. investment costs & {$\left[€ / \mathrm{kW}_{\mathrm{e}}\right]$} & 4433 & 4663 & 1732 & 1801 & 1443 & 1438 & 1859 \\
\hline Fixed $O \& M$ costs & {$[\mathrm{k} € / \mathrm{a}]$} & 451 & 447 & 731 & 725 & 1653 & 1637 & 1952 \\
\hline Thereof personnel expenses & & $47 \%$ & $48 \%$ & $33 \%$ & $34 \%$ & $49 \%$ & $49 \%$ & $51 \%$ \\
\hline \multicolumn{6}{|l|}{ Levelized electricity costs } & 0.0568 & 0.0568 & 0.0616 \\
\hline Reference plant LEC & {$[€ / \mathrm{kW} \mathrm{h}]$} & 0.0667 & 0.0698 & 0.0563 & 0.0563 & 0.0458 & 0.0474 & 0.0474 \\
\hline $\mathrm{CO}_{2}$-avoidance cost & {$[€ / \mathrm{kg}]$} & 0.6732 & 0.5434 & 0.4561 & 0.3602 & 0.2111 & 0.1257 & 0.1099 \\
\hline Solar incremental LED & {$[€ / \mathrm{kW} \mathrm{h}]$} & 0.3960 & 0.3452 & 0.3084 & 0.2540 & 0.1404 & 0.1058 & 0.0985 \\
\hline
\end{tabular}

automation. The reduction potential of the solar LEC is especially high $(>50 \%)$ for small power lev- els. For the largest plant a cost digression of $>20 \%$ is possible, leading to solar LEC below $10 €$ cent/ 


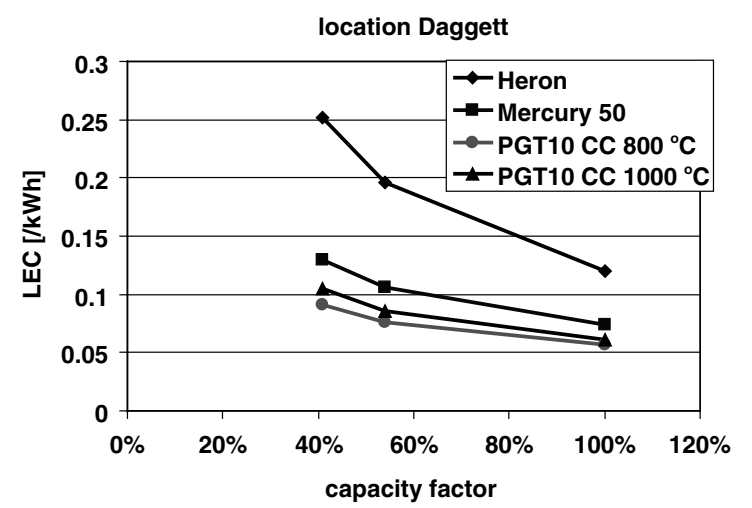

Fig. 12. Results of cost analysis. Total LEC as a function of capacity factor for 2 nd generation plant in Daggett.

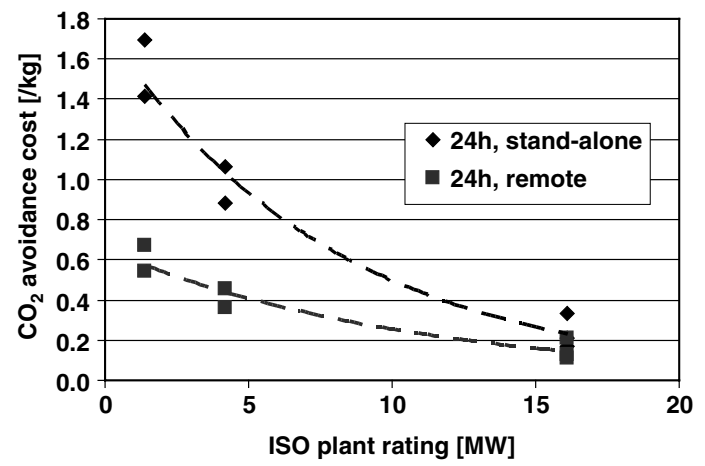

Fig. 13. Results of cost analysis. $\mathrm{CO}_{2}$-avoidance cost for $2 \mathrm{nd}$ generation plant in Daggett as a function of power level.

$\mathrm{kW} \mathrm{h}$. The investment cost is then reduced to $1860 € / \mathrm{kW}(-16 \%)$ and the fixed O\&M costs are reduced to $1950 \mathrm{k} € / \mathrm{a}(-20 \%)$.

Fig. 12 left shows the variation of total LEC for the 2 nd generation plants as a function of capacity factor. With the largest plant (PGT10 CC $1000{ }^{\circ} \mathrm{C}$ ), electricity at an annual solar share of $70 \%$ can be produced at total cost of $10.5 €$ cent/ $\mathrm{kW}$ h (compare to Fig. 10). This can be an interesting option for green power markets. Relating the solar LEC to the annual amount of $\mathrm{CO}_{2}$ that can be avoided when operating the hybrid plant instead of the pure fossil reference plant, the $\mathrm{CO}_{2}$-avoidance costs can be calculated for each individual plant (Fig. 13). For the higher power level a value well below $200 € /$ ton $\mathrm{CO}_{2}$ can be reached.

\section{Further development and market introduction}

At the current status of the development of solarhybrid gas turbine systems with pressurized volu- metric receivers the main issues for further $R \& D$ are:

- verification of O\&M assumptions for the receiver and the power conversion subsystem;

- further increase of the solar share to reduce greenhouse gas emissions;

- further cost reduction of solar components (i.e. heliostats, receiver modules).

Test operation of the $240 \mathrm{~kW}_{\mathrm{e}}$ solar-hybrid system at the PSA was continued until summer 2004 within the HST project, funded by the German Ministry of Environment (BMU). As part of this project one receiver was tested at air outlet temperatures up to $1030{ }^{\circ} \mathrm{C}$. This results in a further increase of the solar share of solar-hybrid power plants. Another future option is the inclusion of high-temperature heat storage systems, also leading to an increased solar share.

Although the cost predictions indicate potential competitive applications in the green power market, the introduction of this new technology is hampered by several factors:

- Power production costs are still higher than with conventional fossil fuel options.

- Up to now, only a few possibilities exist for the funding of hybrid systems with fossil contributions above $30 \%$ (solar shares $<70 \%$ ).

- Exploiting the full potential of high efficiencies of combined cycle plants $(>50 \%)$ requires power levels above $50 \mathrm{MW}_{\mathrm{e}}$; this means a very high investment cost which is not realistic for the introduction of a new technology.

From the latter it is clear that market introduction is mainly possible at lower power levels, with the option of future scale-up. At power levels below $10 \mathrm{MW}_{\mathrm{e}}$, gas turbine systems are mainly used for decentralized power generation with cogeneration of heat or cooling power. First cost assessments for such cogeneration units indicated a potential for solar-hybrid gas turbine units (Sugarmen et al., 2003). Therefore, the planned steps towards market introduction of this new technology are as follows:

1. Gain further experience in long term behavior of the key components.

2. Design and installation of a first prototype plant based on a small gas turbine or microturbine, with cogeneration. 
3. Market introduction of the technology at power levels up to several $\mathrm{MW}_{\mathrm{e}}$, as cogeneration units.

4. Upscaling to power plants with combined cycle for high efficiency.

A first demonstration system is currently under construction in Empoli, Italy. Two small solar tower plants, each with receiver, microturbine, absorption chillers and water heat exchanger, will deliver $160 \mathrm{~kW}_{\mathrm{e}}$, hot water and cooling for a hospital. Other small-scale applications are planned.

\section{Conclusions}

The cost-optimized design and performance prediction for solar-hybrid gas turbine plants in the power levels 1.4 $\mathrm{MW}_{\mathrm{e}}, 4.2 \mathrm{MW}_{\mathrm{e}}$ and $16.1 \mathrm{MW}_{\mathrm{e}}$ for two different locations were shown. An annual average solar to net electric efficiency of up to $19 \%$ was calculated, amongst the highest conversion efficiencies for solar electric technologies. The cost analysis showed total plant investment costs from $7000 € /$ $\mathrm{kW}$ down to below $1800 € / \mathrm{kW}$, depending on power level and solar share. Solar LEC between about $13 €$ cent $/ \mathrm{kW}$ h up to $90 €$ cent $/ \mathrm{kW}$ h were calculated. Using the cost reduction potential that lies in combined design, construction and operation of multiple distributed plants leads to solar LEC of below $10 € c e n t / \mathrm{kWh}$ for an electric power level of 16.1 MW. So, the solar-hybrid gas turbine power technology shows interestingly low cost for solar produced bulk electricity at a moderate power level. The values predicted for ISCC plants can be reached, but with a smaller system (16 MW instead of $310 \mathrm{MW}$ ) and with a significantly higher solar share $(28 \%$ instead of $9 \%$, see chapter 1$)$. The advantage compared to large-scale PV plants and other pure solar systems lies in full dispatchability.

$\mathrm{CO}_{2}$-avoidance cost down to $20 € /$ ton were calculated for this technology. This is an interesting figure especially when compared to published costs for $\mathrm{CO}_{2}$ avoidance through fuel substitution in the conventional utility-scale power sector ranging from 70 to $700 \mathrm{US} \$ /$ ton (e.g. Narula et al., 2002).

The high technical and economical potential of this technology is outlined. While larger units ( $>10-15 \mathrm{MW}$ ) especially combined cycle systems show very low cost for solar produced bulk electricity (which will further decrease with increasing power level), small-scale units $(<5-10 \mathrm{MW})$ should be applied in distributed markets using cogeneration to start market introduction.

\section{Acknowledgement}

This work was partly funded by the European Union under contract no. ENK5-CT-2000-00333.

\section{References}

Becker, M., Böhmer, M. (Eds.), 1989. GAST-The Gas-Cooled Solar Tower Technology Program. Proceedings of the Final Presentation. Springer-Verlag, Berlin.

Buck, R., Lüpfert, E., Téllez, F., 2000. Receiver for solarhybrid gas turbine and CC systems (Refos). In: IEA Solar Thermal 2000 Conference, 8-10 March 2000, Sydney, Australia.

Buck, R., Bräuning, T., Denk, T., Pfänder, M., Schwarzbözl, P., Téllez, F., 2002. Solar-hybrid gas turbine-based power tower systems. Journal of Solar Energy Engineering. Transactions of the ASME 124 (February).

Dersch, J., Geyer, M., Herrmann, U., Jones, S., Kelly, B., Kistner, R., Ortmanns, W., Pitz-Paal, R., Price, H., 2004. Trough integration into power plants - a study on the performance and economy of integrated solar combined cycle systems. Energy 29, 947-959.

Heller, P., Pfänder, M., Denk, T., Téllez, F., Ring, A., 2005. Test and evaluation of a solar powered gas turbine system. Solar Energy, doi:10.1016/j.solener.2005.04.020.

Kurokawa, K. (Ed.), 2003. Energy from the desert. Feasibility of Very Large Scale Photovoltaic Power Generation (VLS-PV) Systems. IEA-PVPS Task 8 Report, James \& James Ltd., London.

Narula, R., Wen, H., Himes, K., 2002. Incremental cost of $\mathrm{CO}_{2}$ reduction in power plants. In: Proceedings of IGTI, ASME Turbo Expo 2002, 3-6 June 2002, Amsterdam, The Netherlands.

Pitz-Paal, R., Jones, S., 1998. A TRNSYS Model Library for Solar Thermal Electric Components (STEC). SolarPACES Technical Report No. III -4/98, Köln, Germany.

Price, H., Lüpfert, E., Kearney, D., Zarza, E., Cohen, G., Gee, R., Mahoney, R., 2002. Advances in parabolic trough solar power technology. Journal of Solar Energy Engineering 124, 109-125.

Schwarzbözl, P., Schmitz, M., Pitz-Paal, R., Buck, R., 2002. Analysis of solar gas turbine systems with pressurized air receivers (Refos). In: Proceedings of 11th SolarPACES International Symposium on Concentrated Solar Power and Chemical Energy Technologies, 4-6 September 2002, Zürich, Switzerland.

Sugarmen, C., Ring, A., Buck, R., Heller, P., Schwarzbözl, P., Téllez, F., Marcos, M.J., Enrile, J., 2003. Solar-hybrid gas turbine power plants-test results and market perspectives. In: Proceedings of ISES Solar World Congress 2003, Göteborg, Sweden.

TRNSYS STEC, 2002. Available from: <http://sel.me.wisc.edu/ trnsys/trnlib/stec/stec.htm>. 